Research Paper

\title{
A Comparative Clinical Study on Five Types of Compression Therapy in Patients with Venous Leg Ulcers
}

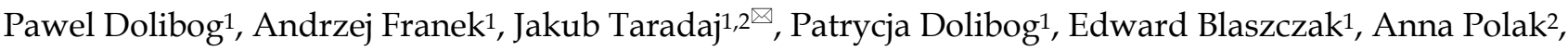 \\ Ligia Brzezinska-Wcislo ${ }^{3}$, Antoni Hrycek ${ }^{4}$, Tomasz Urbanek ${ }^{5}$, Jacek Ziaja ${ }^{6}$, Magdalena Kolanko ${ }^{3}$ \\ 1. Department of Medical Biophysics, Medical University of Silesia in Katowice, Poland \\ 2. Department of Physiotherapy Basics, Academy of Physical Education in Katowice, Poland \\ 3. Department of Dermatology, Medical University of Silesia in Katowice, Poland \\ 4. Depatment of Internal, Autoimmune and Metabolic Medicine, Medical University of Silesia in Katowice, Poland \\ 5. Department of General and Vascular Surgery, Medical University of Silesia in Katowice, Poland \\ 6. Department of General, Vascular and Transplant Surgery, Medical University of Silesia in Katowice, Poland
}

$\triangle$ Corresponding author: Prof. Jakub Taradaj, Department of Physiotherapy Basics, Academy of Physical Education in Katowice, Mikolowska Street 72, building B 40-065, Poland. j.taradaj@awf.katowice.pl

( ) Ivyspring International Publisher. This is an open-access article distributed under the terms of the Creative Commons License (http://creativecommons.org/ licenses/by-nc-nd/3.0/). Reproduction is permitted for personal, noncommercial use, provided that the article is in whole, unmodified, and properly cited.

Received: 2013.09.01; Accepted: 2013.11.25; Published: 2013.12.14

\begin{abstract}
The aim of this study was to compare five types of compression therapy in venous leg ulcers (intermittent pneumatic vs. stockings vs. multi layer vs. two layer short stretch bandages vs. Unna boots). Primary study endpoints were analysis of changes of the total ulcer surface area, volume and linear dimensions inside observed groups. The secondary end points were comparisons between all groups the number of completely healed wounds (ulcer healing rates), Gilman index and percentage change of ulcer surface area. In total, I 47 patients with unilateral venous leg ulcers were included to this study. Participants were randomly allocated to the groups: A, B, C, D and E. After two months the healing rate was the highest in group A (intermittent pneumatic compression) $-57.14 \%, 16 / 28$ patients, B (ulcer stocking system) - 56.66\%, 17/30 patients and C (multi layer short stretch bandage) $-58.62 \%$, I7/29 patients. Significantly much worse rate found in group D (two layer short stretch bandages) - only 16.66\%, 5/30 patients and E (Unna boots) - 20\%, 6/30 patients. The analysis of changes of the percentage of Gilman index and wound total surface area confirmed that intermittent pneumatic compression, stockings and multi layer bandages are the most efficient. The two layer short - stretch bandages and Unna boots appeared again much less effective.
\end{abstract}

Key words: compression stockings, short stretch bandages, Unna boots, venous leg ulcers, wound healing

\section{Introduction}

Venous leg ulcers pose a serious clinical dilemma and an economic burden on health services. About $1 \%-2 \%$ of the whole population and $3 \%-5 \%$ of the population over 65 years of age will suffer from a leg ulcer during their lifetime $[1,2]$. However, in a typical Western population where the average age is steadily increasing, the burden placed upon the health econ- omy by venous ulceration looks set to increase proportionally. Cost effective treatment of venous disorders is therefore vital.

Venous ulcers alone have been estimated to cost the National Health Service $£ 400$ million a year in the United Kingdom [3]. Studies in Germany [4] calculated the mean total cost of a VLU per patient per year 
to be $€ 9569$ ( $€ 8658$ - 92\% direct costs). According to Collins and Seraj [5] the financial burden of venous ulcers is estimated to be $\$ 2$ billion per year in the United States.

The occurrence and the treatment of chronic leg ulcer generate significant costs related to the necessity of often expensive and long-term therapy. In the United States alone, between 500000 and 1000000 people suffer from chronic leg ulcers, the majority of which result from venous insufficiency. An improvement in the knowledge concerning venous ulcer pathophysiology as well as an implementation of modern therapy such tissue debridement, colloid dressings, apligraf application (Tissue, Infection, Moisture and Edge framework - TIME strategy - in chronic wound treatment) significantly improved the rate of the healed ulcers. However, despite this progress, the number of patients with resistive or recurrent venous ulcer still remains relatively high. Some European studies $[1,4]$ have reported that recurrence rate of venous ulcers is $20 \%$ to $23 \%$ in 5 year follow up, which has a considerable impact on health and quality of life in terms of patient pain and social isolation. This fact stimulates new findings as well as an implementation of new methods and medicines in this field $[6,7]$.

Clinical studies [8-20] have examined the efficient effects (healing outcomes) of compression therapy on leg ulcers. But in the literature, there are many methods of applying external graduated compression, such as elasticised bandages, Unna's boots, multilayer elastic compression bandages, short stretch bandages and elastomeric hosiery. The differences in effectiveness of various types of compression are not clear. The authors are still not sure as to which compression techniques, and pressure values are clinically the best (Table 1), easy to use and not expensive.

The aim of our study was to compare five types of compression therapy in venous leg ulcers (intermittent pneumatic vs. stockings vs. multi layer vs. two layer short stretch bandages vs. Unna boots). Primary study endpoints were analysis of changes of the total ulcer surface area, volume and linear dimensions inside observed groups. The secondary end points were comparisons between all groups the number of completely healed wounds (ulcer healing rates), Gilman index and percentage change of ulcer surface area.

\section{Materials and methods}

All participants provided informed consent to this project that was approved by the local Bioethics Committee of the Medical University of Silesia in Katowice (protocol number NN/6501/101/06). The subjects signed written agreement forms. The trial is registered in Australian and New Zealand Clinical Trials Registry (ACTRN12613001213730).

Table I. Compression therapy and literature

\begin{tabular}{|c|c|c|c|}
\hline Authors & Material & Methods & Results \\
\hline Duby et al. [9] & $\begin{array}{l}\text { A }-25 \text { patients } \\
B-25 \text { patients } \\
\text { C }-26 \text { patients }\end{array}$ & $\begin{array}{l}\text { A - short stretch bandages } \\
\text { B - multi layer compression } \\
\text { C - drug therapy }\end{array}$ & $\begin{array}{l}\mathrm{A}-{ }^{*} 40 \%,{ }^{* *} 60 \% \text { after } 12 \text { weeks } \\
\mathrm{B}-{ }^{*} 44 \%,{ }^{*} 76 \% \text { after } 12 \text { weeks } \\
\mathrm{C}-{ }^{*} 34.5 \%,{ }^{* *} 43 \% \text { after } 12 \text { weeks }\end{array}$ \\
\hline Colgan et al. [10] & $\begin{array}{l}\text { A }-10 \text { patients } \\
B-10 \text { patients } \\
C-10 \text { patients }\end{array}$ & $\begin{array}{l}\text { A - Unna boots } \\
\text { B - multi layer compression } \\
\text { C - drug therapy }\end{array}$ & $\begin{array}{l}\text { A - }{ }^{*} 60 \% \text { after } 12 \text { weeks } \\
\text { B - }{ }^{*} 70 \% \text { after } 12 \text { weeks } \\
\text { C - }{ }^{*} 20 \% \text { after } 12 \text { weeks }\end{array}$ \\
\hline Danielsen et al. [11] & $\begin{array}{l}\text { A - } 20 \text { patients } \\
\text { B - } 20 \text { patients }\end{array}$ & $\begin{array}{l}\text { A - medium stretch bandages } \\
\text { B - short stretch bandages }\end{array}$ & $\begin{array}{l}\text { A - }{ }^{* *} 45 \% \text { after } 4 \text { weeks } \\
\text { B - }{ }^{*} 72 \% \text { after } 4 \text { weeks }\end{array}$ \\
\hline Vowden [12] & 50 patients & intermittent compression & $64.5 \%$ and $80 \%$ after 12 and 20 weeks \\
\hline Partsch et al [13] & $\begin{array}{l}\text { A - } 53 \text { patients } \\
\text { B - } 59 \text { patients }\end{array}$ & $\begin{array}{l}\text { A - multi layer compression } \\
\text { B - short stretch bandages }\end{array}$ & $\begin{array}{l}\text { A - }{ }^{*} 62 \% \text { after } 16 \text { weeks } \\
\text { B - }{ }^{*} 73 \% \text { after } 16 \text { weeks }\end{array}$ \\
\hline Meyer et al. [14] & $\begin{array}{l}\text { A - } 57 \text { patients } \\
\text { B - } 55 \text { patients }\end{array}$ & $\begin{array}{l}\text { A - short stretch bandages } \\
\text { B - medium stretch bandages }\end{array}$ & $\begin{array}{l}\text { A - }{ }^{*} 58 \% \text { after } 24 \text { weeks } \\
\text { B - }{ }^{*} 62 \% \text { after } 24 \text { weeks }\end{array}$ \\
\hline O'Brien et al. [15] & $\begin{array}{l}\text { A }-100 \text { patients } \\
B-100 \text { patients }\end{array}$ & $\begin{array}{l}\text { A - multi layer compression } \\
\text { B - drug therapy }\end{array}$ & $\begin{array}{l}\text { A - }{ }^{*} 54 \% \text { after } 12 \text { weeks } \\
\text { B - * } 34 \% \text { after } 12 \text { weeks }\end{array}$ \\
\hline Franks et al. [16] & $\begin{array}{l}\text { A }-70 \text { patients } \\
\text { B }-86 \text { patients }\end{array}$ & $\begin{array}{l}\text { A - multi layer compression } \\
\text { B - short stretch bandages }\end{array}$ & $\begin{array}{l}\text { A - }{ }^{*} 69 \% \text { after } 24 \text { weeks } \\
\text { B - } 73 \% \text { after } 24 \text { weeks }\end{array}$ \\
\hline Junger et al. [17] & $\begin{array}{l}\text { A }-60 \text { patients } \\
B-61 \text { patients }\end{array}$ & $\begin{array}{l}\text { A - stockings } \\
\text { B - bandages }\end{array}$ & $\begin{array}{l}\text { A - * } 47.5 \% \text { after } 12 \text { weeks } \\
\text { B - }{ }^{*} 31.7 \% \text { after } 12 \text { weeks }\end{array}$ \\
\hline Vanscheidt et al. [18] & 116 patients & Unna boots & ${ }^{*} 25.9 \%,{ }^{* *} 42.9 \%$ after 12 weeks \\
\hline Brizzio et al. [19] & $\begin{array}{l}\text { A }-21 \text { patients } \\
B-14 \text { patients }\end{array}$ & $\begin{array}{l}\text { A - stockings } \\
\text { B - multi layer bandages }\end{array}$ & $\begin{array}{l}\text { A - }{ }^{*} 90 \% \text { after } 24 \text { weeks } \\
\text { B - }{ }^{*} 57 \% \text { after } 24 \text { weeks }\end{array}$ \\
\hline
\end{tabular}

*healing rate

${ }^{* *}$ percentage decrease of wound area 


\section{Settings and Participants}

A prospective, randomized, comparative study was conducted from June 2010 to January 2013 in Silesia, Poland. Patients with the venous leg ulcers were included in the study. The exclusion criteria were: (1) an ankle brachial pressure index (ABPI) lower than 1.0, (2) diabetes, (3) cancer, (4) peripheral nerve injury,
(5) rheumatoid arthritis, (6) ventricular arrhythmia, (7) cardiac pacemaker, (8) ulcer surgery, (9) skin infection, (10) pregnancy and (11) after steroid therapy, (12) bilateral ulcers. The (13) lymphedema, (14) pulmonary edema and (15) congestive heart failure, (16) chronic renal failure were exclusion criteria in our protocol too (Figure 1).

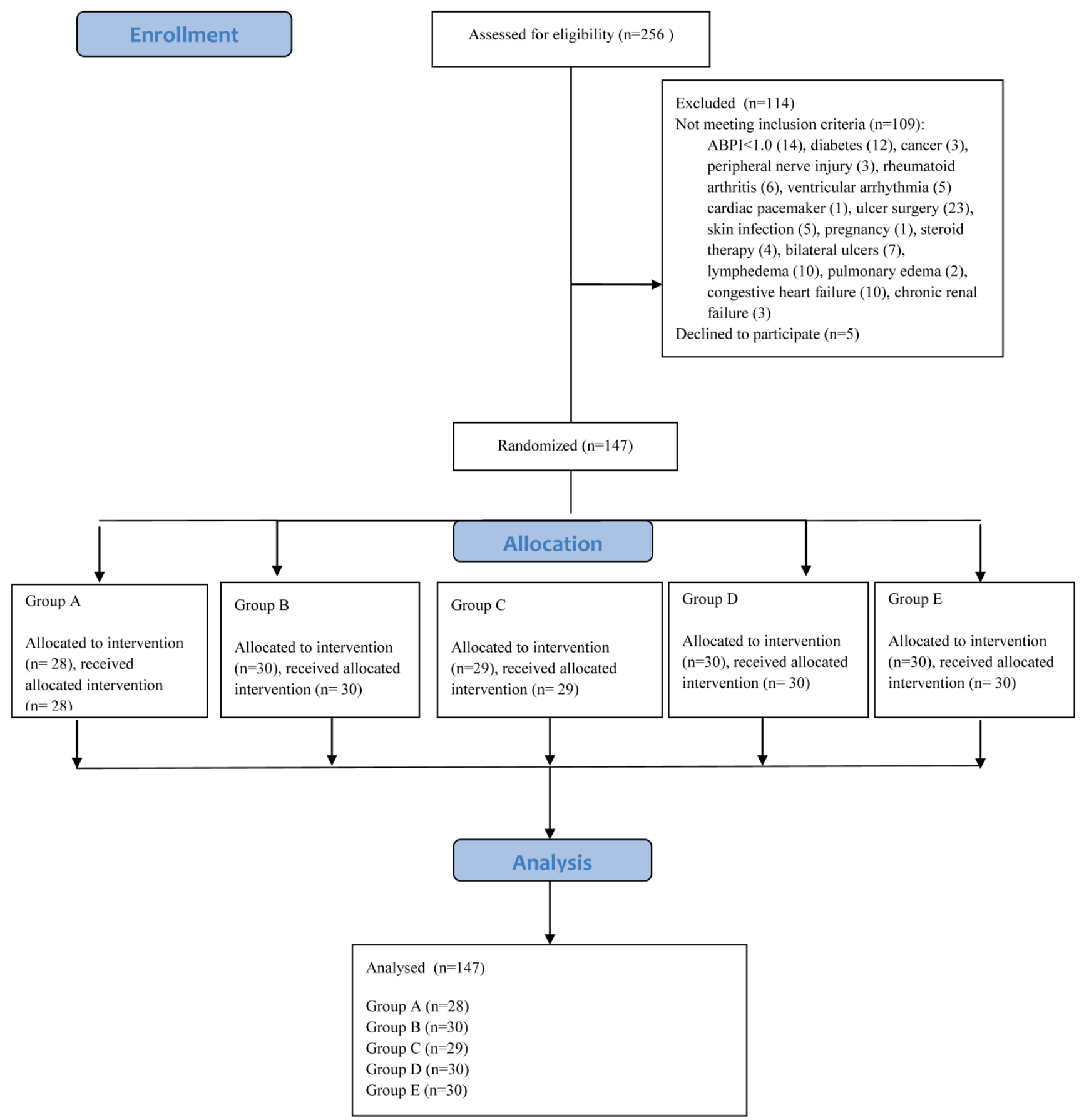

Figure I. Flow diagram through the study 
In total, 117 patients with unilateral venous leg ulcers were included to this study. Participants were randomly allocated to four groups A, B, C, D and E.

All ulcers in these groups were diagnosed as venous. Patients were examined (9 segments - upper and lower greater saphenous vein, short saphenous vein, proximal and distal femoral vein, proximal and distal popliteal vein, saphenofemoral junction and saphenopopliteal junction) by duplex scanning (EUB 555, Hitachi Inc, Japan). The thigh veins were examined with the participant standing, whereas the calf veins were examined in the sitting position, with the leg dependent. Each vein segment was imaged both in crosssection and longitudinally. When the vessels were imaged in cross -section, the direction of the Doppler shift was represented by a color scale over the blood vessels (red $=$ flow in proximal direction, blue $=$ flow in distal, retrograde direction). In longitudinal images, the numerical velocity of red blood cells within each segment was plotted against time. A transient increase in proximal flux was generated by manually squeezing the limb distal to the segment under examination. On releasing the distal compression, significant amounts of blood pass distally (pathological reflux) if the valve proximal to the site of examination does not close properly. For assessment of the calf veins, the foot was compressed; for assessment of the thigh veins, the calf was compressed. Criteria for pathological reflux were duration $0.5 \mathrm{~s}$ and peak reflux velocity $10 \mathrm{~cm} / \mathrm{s}$. The Doppler examination was provided on both legs.

All patients had the symptoms of chronic venous insufficiency (CVI), i.e. edema, skin hyperpigmentation and lipo-dermatosclerosis of the affected limb. The body mass index (BMI) was calculated for all patients. According to international norms, a BMI higher than $30 \mathrm{~kg} / \mathrm{m} 2$ indicated adipositas. The number of smokers was recorded as well. According to inclusion/exclusion criteria protocol the recruited participants before experiment had complex tests measured twice within the past three months (standard blood morphology, immunological studies, $\mathrm{HbA}_{1 \mathrm{c}}$, cholesterol panel and liver enzymes, serum creatinine/glomerular filtration rate, urine testing, ECG).

\section{Randomization and Intervention}

Computer-generated random numbers were sealed in sequentially numbered envelopes and group allocation was independent of time and persons delivering the treatment. The physician allocating patients to groups had 147 envelopes, each containing a piece of paper marked with A, B, C, D and E groups. The physician would draw and open an envelope in the presence of a physiotherapist to see the symbol and direct the patient to one of the comparative groups accordingly. The patients were treated in Department of Dermatology of Medical University of Silesia.

The study design, methodology, and treatment were programmed by coordinators (physiotherapist, general and vascular surgeons, and an internist from Department of Physiotherapy Basics of Academy of Physical Education, Department of Internal Medicine, and Department of Vascular Surgery of Medical University of Silesia). Standard care, planimetry measurements, and data collection were provided by a nurse from Department of Dermatology of Medical University of Silesia. The compression therapy was performed by a physiotherapist from Department of Dermatology of Medical University of Silesia. The final statistical analysis was performed by a technician form Department of Medical Biophysics of Medical University of Silesia. A nurse from hospital collected data and coded them to the Excel database. The "blinded" results were transferred to Statistica version 10.0 database by a technician from Department of Medical Biophysics. The research coordinators had no contact with patients and could not identify them.

All participating facilities provided patients a standard regimen of drug therapy (standard regimen was carried out for 2 months to begin our experiment - application one of five compression procedures in following group), including micronized purified flavonoid fraction $450 \mathrm{mg}$ diosmin, $50 \mathrm{mg}$ hesperidin, 2 tablets of $500 \mathrm{mg}$ (Daflon 500) once daily.

Patients in group A received 12 - chamber intermittent pneumatic compression therapy. The Flowtron Hydroven 12 System device (Huntleigh Healthcare, UK) was applied to compress the cuff covers the foot, lower leg, knee and thigh. Cuff length was $109 \mathrm{~cm}$ (a foot for $33 \mathrm{~cm}$ ). Cuff expanded from foot (circumference $38 \mathrm{~cm}$ ) to thigh (circumference 71 $\mathrm{cm}$ ). All patients were subjected to a pressure of 60 $\mathrm{mmHg}$ at the ankle. In the upper chamber pressure was exerted smaller and decreases with the height (40 $\mathrm{mmHg}$ in the chamber at the level of the groin. Ventricular filling time was $60 \mathrm{~s}$, and a discharge time of $30 \mathrm{~s}$. A single setting lasted 60 min during treatment, patients were lying. The pneumatic compressions were provided once daily, 5 times a week for 2 months.

Patients in group B were treated with special ulcer stocking system Ulcer X (Sigvaris, Gianzoni \& Cie AG, Switzerland) providing pressure $30-40$ $\mathrm{mmHg}$ at the ankle. The system were put on the leg at the outpatient clinic every morning and worn whole day (about 10-12 hours); and put off on night.

Patients in group $C$ were treated with multi layer short-stretch bandaging (Sigvaris, Gianzoni \& Cie AG, Switzerland). The pressure values were also stand- 
ardized in use of Kikuhime (Advancis Medical, UK) manometer $(45-50 \mathrm{mmHg}$ for superficial reflux and $50-55 \mathrm{mmHg}$ for superficial with deep venous reflux). Bandages were applied in four layers with spinal turns on foot and turns in eight on calf. The bandages were worn day (10 - 12 hours) and put off on night.

Patients in group D were treated with two layer short-stretch bandaging (Sigvaris, Gianzoni \& Cie AG, Switzerland). The pressure values were also standardized in use of Kikuhime manometer $(20-25 \mathrm{mmHg}$ for superficial reflux and $25-30 \mathrm{mmHg}$ for superficial with deep venous reflux). Treatment was with the same methodology as in group C.

Patients from group E underwent the compression treatment by means of Unna's boot. After rinsing the wound with physiological sodium chloride solution, Unna's rigid paste bandage was tied around the limbs from below the toes up to the knee. This dressing was changed every 7 days.

In all groups therapy lasted two months. The compressions were applied by a clinic physiotherapist, who was a professional practitioner (with 15 years of experience). The therapist completed a course on management of leg ulcers and additional training before experiment (20 days to practice applying bandaging with Kikuhime manometer).

\section{Outcomes and measurements}

The therapy progress was assessed using analysis of healing rates and digital planimetry - total ulcer surface area $\left(\mathrm{cm}^{2}\right)$, length and width $(\mathrm{cm})$, volume $\left(\mathrm{cm}^{3}\right)$ - in use of digitizer (Kurta XGT, Altek Inc, USA). Ulcers were photographed and size was recorded weekly by transferring their homothetic, congruent images onto transparent film sheets. The contours showed wound perimeters and granulation tissue areas and were also used to measure wound longest lengths and longest (perpendicular) widths with a centimeter ruler. Wound depth was measured using a digital caliper with a depth gauge (MIB-Messzeuge IP67 Germany) at the site where the wound was the deepest. The tip of the gauge had a soft, disposable, sterile cap that prevented the bed of the wound from being damaged. The site where depth was measured was also marked on the contour. The images then were measured with a planimeter. The electronic equipment measuring pressure ulcer area and volume consisted of a digitizer wired to a personal computer with upgraded software (C-GEO v. 4.0 Nadowski, Poland) for calculating and storing pressure ulcer area, perimeter, and volume measurements.

The healing process between groups were assessed using:

- a modified Gilman Index [21], which is a corre- lation between changes in surface related to the

- shape of the wound. It was used to analyze the healing process compared to circumference of the wound.

- percentage changes of the total ulcer area

$$
\begin{gathered}
\mathrm{d}-\text { Gilman Index }(\mathrm{cm}) \\
d=\frac{\Delta S}{p}=\frac{S_{I}-S_{F}}{\left(C_{F}+C_{I}\right) / 2}=\frac{2\left(S_{I}-S_{F}\right)}{C_{F}+C_{I}}
\end{gathered}
$$

$\mathrm{S}_{\mathrm{I}}$ - initial total area $\left(\mathrm{cm}^{2}\right)$

$\left(\mathrm{cm}^{2}\right)$

$S_{F}$ - final wound total area after two months

$\mathrm{C}_{\mathrm{I}}$ - initial circumference $(\mathrm{cm})$

$C_{F}$ - final wound circumference after two months $(\mathrm{cm})$

$\Delta \mathrm{S} \%$ - percentage change of the total surface area

$$
\Delta S \%=\frac{\left(S_{I}-S_{F}\right) * 100 \%}{S_{I}}
$$

$\mathrm{S}_{\text {I }}$ - initial total area $\left(\mathrm{cm}^{2}\right)$ $\left(\mathrm{cm}^{2}\right)$

$\mathrm{S}_{\mathrm{F}}$ - final wound total area after two months

\section{Statistics}

The $x^{2}$ independence test and non-parametric Kruskal-Wallis two - way analysis, which is an element of a module of the analysis of variance, were used for comparing indicators, which characterized patients in all comparative groups. Outcome measurements were compared between the groups by using Fisher test, Kruskal-Wallis analysis of variance (post hoc Tukey's test) and inside the groups non-parametric Wilcoxon signed - rank test. Two sided " $\mathrm{P}$ " (level of significance) values of less than 0.05 were considered to be statistically significant.

\section{Results}

The participant characteristics assessed before randomization are shown in Table 2 and 3. Patients were evaluated using the clinical, etiological, anatomical and pathological elements (CEAP) classification of chronic venous insufficiency (Table 4) and were homogenous.

Treatment in all comparative groups appeared efficient (Table 5). However, after completion of the study, it was found that the healing rate (number of completely healed ulcer) was the highest in group A (intermittent pneumatic compression) - 57.14\%, 16/28 patients, B (ulcer stocking system) - 56.66\%, 17/30 patients and C (multi layer short stretch bandage) $58.62 \%, 17 / 29$ patients (" $\mathrm{P}$ " values and more in Figure 2). Significantly much worse rate found in group $D$ (two layer short stretch bandages) - only $16.66 \%, 5 / 30$ 
patients and E (Unna boots) - 20\%, 6/30 patients (see Figure 2).

The analysis of changes of the percentage of Gilman index and wound total surface area confirmed that intermittent pneumatic compression, stockings and multi layer bandages are the most efficient. The two layer short - stretch bandages and Unna boots appeared again much less effective (other details in Figure 3 and 4).

Table 2. Characteristics of participants and ulcers

\begin{tabular}{|c|c|c|c|c|c|c|}
\hline & Group A & Group B & Group C & Group D & Group E & $\mathbf{P}$ \\
\hline Number of patients* & 28 & 30 & 29 & 30 & 30 & $>0.05$ \\
\hline \multicolumn{6}{|l|}{ Age (years) ${ }^{* *}$} & \multirow[t]{5}{*}{$>0.05$} \\
\hline Range & $51-82$ & $48-81$ & $53-81$ & $40-69$ & $40-72$ & \\
\hline Average & 62.24 & 63.88 & 63.47 & 64.03 & 65.13 & \\
\hline Median & 61.89 & 63.12 & 62.83 & 64.01 & 65.19 & \\
\hline $\mathrm{SD}$ & 9.34 & 10.11 & 9.89 & 10.11 & 10.87 & \\
\hline \multicolumn{6}{|l|}{ Sex ${ }^{*}$} & \multirow[t]{3}{*}{$>0.05$} \\
\hline Female & 19 & 20 & 18 & 20 & 20 & \\
\hline Male & 9 & 10 & 11 & 10 & 10 & \\
\hline \multicolumn{6}{|l|}{ Weight $(\mathrm{kg})^{* *}$} & \multirow[t]{5}{*}{$>0.05$} \\
\hline Range & $62-95$ & $70-119$ & $54-99$ & $71-109$ & $68-91$ & \\
\hline Average & 80.11 & 86.03 & 80.11 & 83.23 & 81.23 & \\
\hline Median & 80.09 & 87.01 & 79.89 & 83.01 & 82.15 & \\
\hline $\mathrm{SD}$ & 11.22 & 17.12 & 11.92 & 13.12 & 12.01 & \\
\hline \multicolumn{6}{|l|}{ Height $(\mathrm{cm})^{* *}$} & \multirow[t]{5}{*}{$>0.05$} \\
\hline Range & $147-180$ & $160-175$ & $164-180$ & $166-188$ & $164-189$ & \\
\hline Average & 162.11 & 166.05 & 169.89 & 169.02 & 169.89 & \\
\hline Median & 163,44 & 167.21 & 170.04 & 170.11 & 171.04 & \\
\hline $\mathrm{SD}$ & 12.14 & 9.12 & 10.88 & 10.22 & 11.02 & \\
\hline \multicolumn{6}{|l|}{ Localization of VLU* } & \multirow[t]{4}{*}{$>0.05$} \\
\hline Medial ankle & 17 & 18 & 16 & 18 & 18 & \\
\hline Lateral ankle & 7 & 9 & 8 & 9 & 9 & \\
\hline Frontal surface on tibia & 4 & 3 & 5 & 3 & 3 & \\
\hline \multicolumn{6}{|l|}{ Duration of VLU (months) ${ }^{* *}$} & \multirow[t]{5}{*}{$>0.05$} \\
\hline Range & $1-36$ & $5-46$ & $1-38$ & $2-36$ & $4-38$ & \\
\hline Average & 30.12 & 32.67 & 28.88 & 29.81 & 29.89 & \\
\hline Median & 32.02 & 34.02 & 29.12 & 30.12 & 31.01 & \\
\hline SD & 48.56 & 48.22 & 35.23 & 35.04 & 35.78 & \\
\hline \multicolumn{6}{|l|}{ Initial wound size ${ }^{* *}\left(\mathrm{~cm}^{2}\right)$} & \multirow[t]{5}{*}{$>0.05$} \\
\hline Range & $0.3-72.6$ & $1.2-40.2$ & $3.9-46.6$ & $4.7-40.1$ & $5.2-37.3$ & \\
\hline Average & 25.16 & 24.41 & 22.09 & 22.44 & 21.89 & \\
\hline Median & 22.80 & 23.12 & 20.02 & 19.99 & 18.39 & \\
\hline SD & 31.17 & 20.23 & 14.01 & 11.87 & 10.11 & \\
\hline
\end{tabular}

*the $\chi^{2}$ test

** the Kruskal - Wallis analysis

Table 3. Other clinical findings of participants in the trial

\begin{tabular}{|c|c|c|c|c|c|c|}
\hline & Group A & Group B & Group C & Group D & Group E & \multirow[t]{2}{*}{$\mathbf{P}$} \\
\hline & n (\%) & n (\%) & n (\%) & n (\%) & n (\%) & \\
\hline $\begin{array}{l}\text { Edema, skin hyperpigmentation, lipo - } \\
\text { dermatosclerosis }\end{array}$ & $28(100)$ & $30(100)$ & $29(100)$ & $30(100)$ & $30(100)$ & $>0.05$ \\
\hline Adipositas $\left(\mathrm{BMI}>30 \mathrm{~kg} / \mathrm{m}^{2}\right)$ & $14(50)$ & $15(50)$ & $14(48)$ & $15(30)$ & $14(47)$ & $>0.05$ \\
\hline Smokers & $4(14)$ & $5(17)$ & $4(13)$ & $5(17)$ & $4(13)$ & $>0.05$ \\
\hline \multicolumn{6}{|l|}{ CVI } & \multirow[t]{3}{*}{$>0.05$} \\
\hline unilateral & $14(50)$ & $15(50)$ & $15(52)$ & $15(50)$ & $15(50)$ & \\
\hline bilateral & $14(50)$ & $15(50)$ & $14(48)$ & $15(50)$ & $15(50)$ & \\
\hline
\end{tabular}

the $x^{2}$ test 
Table 4. The CEAP in patients with venous leg ulcers

\begin{tabular}{|c|c|c|c|c|c|c|}
\hline CEAP class & Group A & Group B & Group C & Group D & Group E & $\mathbf{P}$ \\
\hline $\mathrm{C}_{6} \mathrm{E}_{\mathrm{P}} \mathrm{A}_{\mathrm{S} 2,3} \mathrm{P}_{\mathrm{R}}$ & 13 & 13 & 13 & 14 & 13 & $>0.05$ \\
\hline $\mathrm{C}_{6} \mathrm{E}_{\mathrm{P}} \mathrm{A}_{\mathrm{S} 4} \mathrm{P}_{\mathrm{R}}$ & 6 & 7 & 7 & 6 & 7 & $>0.05$ \\
\hline $\mathrm{C}_{6} \mathrm{E}_{\mathrm{P}} \mathrm{A}_{\mathrm{S} 2 \mathrm{D} 13} \mathrm{P}_{\mathrm{R}}$ & 4 & 5 & 3 & 5 & 4 & $>0.05$ \\
\hline $\mathrm{C}_{6} \mathrm{EPA}_{\mathrm{P} 3 \mathrm{D} 13} \mathrm{P}_{\mathrm{R}}$ & 3 & 3 & 3 & 2 & 2 & $>0.05$ \\
\hline $\mathrm{C}_{6} \mathrm{E}_{\mathrm{P}} \mathrm{A}_{\mathrm{S} 2,3 \mathrm{D} 13,14 \mathrm{P} 18 \mathrm{P}_{\mathrm{R}}}$ & 1 & 1 & 2 & 2 & 3 & $>0.05$ \\
\hline $\mathrm{C}_{6} \mathrm{E}_{\mathrm{S}} \mathrm{A}_{\mathrm{S} 2,3 \mathrm{D} 13,14 \mathrm{P} 18 \mathrm{P}_{\mathrm{R}}}$ & 1 & 1 & 1 & 1 & 1 & $>0.05$ \\
\hline Total number of patients & 28 & 30 & 29 & 30 & 30 & \\
\hline
\end{tabular}

*the $\chi^{2}$ test

Legends:

$\mathrm{C}_{6} \mathrm{E}_{\mathrm{P}} \mathrm{A}_{\mathrm{s} 2,3} \mathrm{P}_{\mathrm{R}}$ (open ulcer, primary etiology, venous reflux in upper and lower segments of greater saphenous vein)

$\mathrm{C}_{6} \mathrm{E}_{\mathrm{P}} \mathrm{A}_{S 4} \mathrm{P}_{\mathrm{R}}$ (open ulcer, primary etiology, venous reflux in short saphenous vein)

$\mathrm{C}_{6} \mathrm{E}_{\mathrm{P}} \mathrm{A}_{\mathrm{S} 2, \mathrm{D} 13} \mathrm{P}_{\mathrm{R}}$ (open ulcer, primary etiology, venous reflux in upper segments of greater saphenous and femoral vein)

$\mathrm{C}_{6} \mathrm{E}_{\mathrm{P}} \mathrm{A}_{\mathrm{s} 3, \mathrm{D} 13} \mathrm{P}_{\mathrm{R}}$ (open ulcer, primary etiology, venous reflux in lower segments of greater saphenous and femoral vein)

$\mathrm{C}_{6} \mathrm{E}_{\mathrm{P}} \mathrm{A}_{\mathrm{S} 2,3 \mathrm{D} 13} \mathrm{P}_{\mathrm{R}}$ (open ulcer, primary etiology, venous reflux in upper/lower segments of greater saphenous and femoral vein

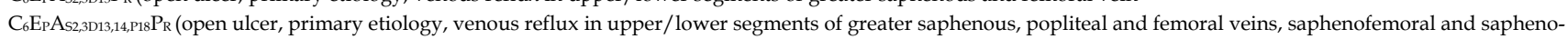
popliteal junctions)

Table 5. Results in patients with venous leg ulcers

\begin{tabular}{|c|c|c|c|}
\hline & Group & $\begin{array}{l}\text { Average } \pm \text { SD } \\
\text { Before therapy After therapy }\end{array}$ & $\mathbf{P}$ \\
\hline \multirow[t]{5}{*}{ Total ulcer surface area $\left(\mathrm{cm}^{2}\right)$} & $\mathrm{A}$ & $25.16 \pm 31.1710 .13 \pm 20.88$ & 0.01 \\
\hline & B & $24.41 \pm 20.239 .67 \pm 20.02$ & 0.01 \\
\hline & $\mathrm{C}$ & $22.09 \pm 14.018 .12 \pm 17.23$ & 0.01 \\
\hline & $\mathrm{D}$ & $22.44 \pm 11.8716 .27 \pm 20.23$ & 0.03 \\
\hline & $\bar{E}$ & $21.89 \pm 10.1115 .78 \pm 19.57$ & 0.03 \\
\hline \multirow[t]{5}{*}{ Length $(\mathrm{cm})$} & $\mathrm{A}$ & $5.78 \pm 3.023 .21 \pm 4.88$ & 0.02 \\
\hline & $\mathrm{B}$ & $5.11 \pm 3.113 .25 \pm 5.33$ & 0.02 \\
\hline & $\mathrm{C}$ & $4.56 \pm 3.093 .01 \pm 5.11$ & 0.02 \\
\hline & $\mathrm{D}$ & $4.87 \pm 4.033 .89 \pm 5.23$ & 0.03 \\
\hline & $\mathrm{E}$ & $4.76 \pm 3.983 .71 \pm 5.03$ & 0.03 \\
\hline \multirow[t]{5}{*}{ Width (cm) } & $\mathrm{A}$ & $3.78 \pm 2.892 .51 \pm 4.99$ & 0.02 \\
\hline & $\mathrm{B}$ & $3.27 \pm 2.392 .32 \pm 4.14$ & 0.02 \\
\hline & $\mathrm{C}$ & $3.22 \pm 1.712 .38 \pm 5.03$ & 0.02 \\
\hline & $\mathrm{D}$ & $3.32 \pm 2.022 .89 \pm 5.23$ & 0.03 \\
\hline & $E$ & $3.12 \pm 1.892 .72 \pm 5.11$ & 0.03 \\
\hline \multirow[t]{5}{*}{ Volume $\left(\mathrm{cm}^{3}\right)$} & $\mathrm{A}$ & $2.39 \pm 3.110 .38 \pm 2.12$ & 0.01 \\
\hline & $\mathrm{B}$ & $2.44 \pm 4.040 .41 \pm 2.11$ & 0.01 \\
\hline & $\mathrm{C}$ & $1.78 \pm 4.760 .42 \pm 2.21$ & 0.01 \\
\hline & $\mathrm{D}$ & $1.67 \pm 4.020 .39 \pm 2.76$ & 0.01 \\
\hline & $E$ & $1.45 \pm 3.880 .41 \pm 2.67$ & 0.01 \\
\hline
\end{tabular}

*Wilcoxon test

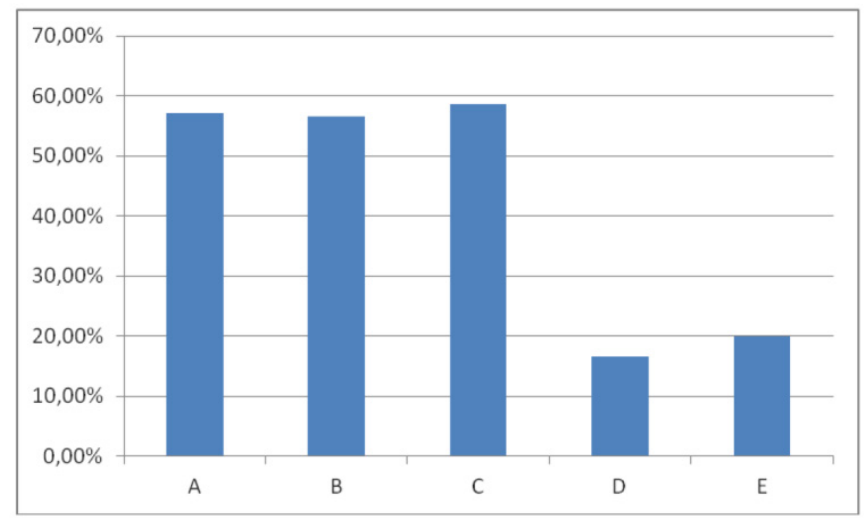

Figure 2. Comparison between groups in terms of healing rate. *Fisher test. Legends: - groups $A$ and $D(57.14 \%$ vs. $16.66 \%, P=0.03)$, - groups $B$ and $D(56.66 \%$ vs. $16.66 \%, P=0.03)$, - groups $C$ and $D(58.62 \%$ vs. $16.66 \%$, $P=0.03)$, - groups $A$ and $E(57.14 \%$ vs. $20.00 \%, P=0.03)$, - groups $B$ and $E$ ( $56.66 \%$ vs. $20.00 \%, P=0.03)$, - groups $C$ and $E(58.62 \%$ vs. $20.00 \%, P=0.03)$. 


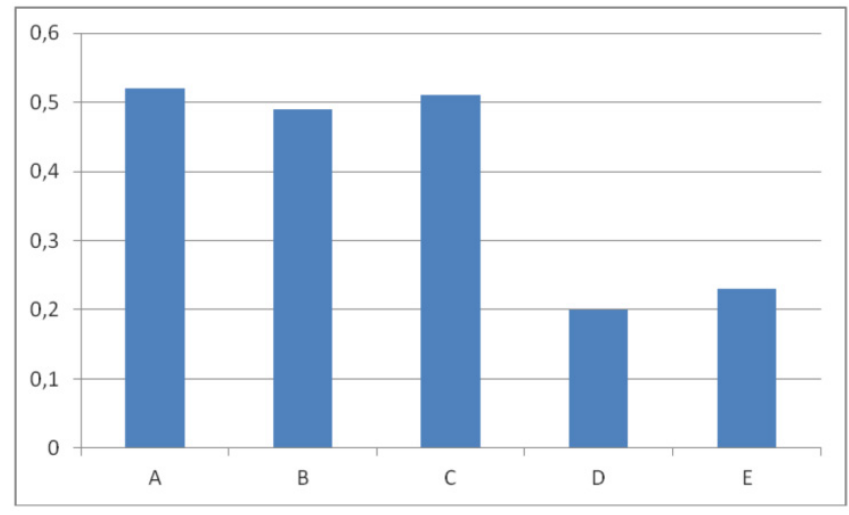

Figure 3. Comparison between groups in terms of Gilman index [cm]. * the Kruskal-Wallis analysis. Legends: - groups $A$ and $D(0.52 \mathrm{~cm}$ vs. 0.20 $\mathrm{cm}, P=0.04)$, - groups $B$ and $D(0.49 \mathrm{~cm}$ vs. $0.20 \mathrm{~cm}, P=0.04)$, - groups $C$ and $D(0.5 \mathrm{I} \mathrm{cm}$ vs. $0.20 \mathrm{~cm}, P=0.04)$, - groups $A$ and $E(0.52 \mathrm{~cm}$ vs. $0.23 \mathrm{~cm}$, $P=0.04)$, - groups $B$ and $E(0.49 \mathrm{~cm}$ vs. $0.23 \mathrm{~cm}, P=0.04)$, - groups $C$ and $E$ $(0.5 \mathrm{I} \mathrm{cm}$ vs. $0.23 \mathrm{~cm}, \mathrm{P}=0.04)$.

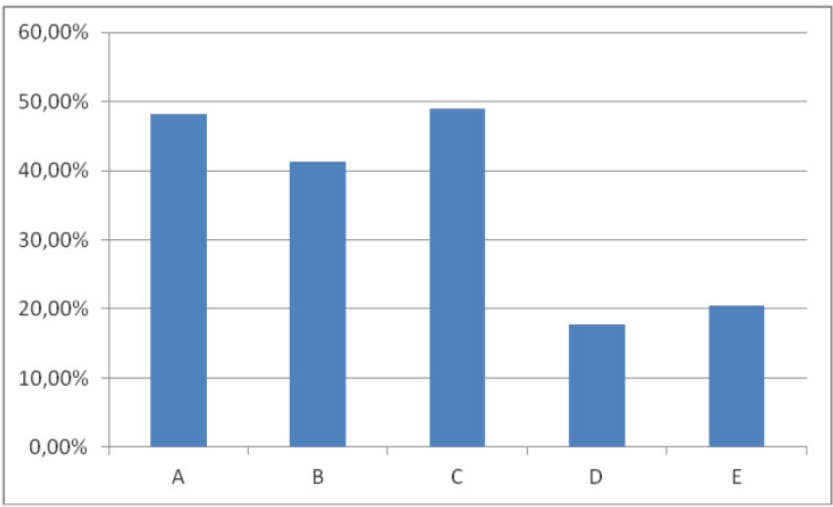

Figure 4. Comparison between groups in terms of change of the percentage ulcer size. * the Kruskal-Wallis analysis. Legends: - groups $A$ and $D$ ( $48.11 \%$ vs. $17.77 \%, P=0.04)$, - groups $B$ and $D(41.22 \%$ vs. $17.77 \%, P=0.04)$, - groups $C$ and $D(49.02 \%$ vs. $17.77 \%, P=0.04)$, - groups $A$ and $E(48.11 \%$ vs. $20.48 \%, P=0.04)$, - groups $B$ and $E(4 \mid .22 \%$ vs. $20.48 \%, P=0.04)$, - groups $C$ and $E(49.02 \%$ vs. $20.48 \%, P=0.04)$.

\section{Discussion}

In our trial the most effective therapeutic procedure for the treatment of venous leg ulcers is the use of intermittent pneumatic compression, stockings and multi layer compression bandaging (on similar level). However in this study, two - layer compression therapy with bandages proved to be the least effective.

Researchers have not analyzed so far such various forms of compression therapy in one prospective, randomized, controlled, clinical trial. This study is the first attempt of comparing such many compression methods and we are able only to relate our results to incomplete data in the literature.

There is only one reliable meta - analysis (Cochrane Review) connected with intermittent pneumatic compression in venous leg ulcers. Nelson et al. [22] in 2011 year included trials that compared the effects of pneumatic compression with control (sham or no compression) or made comparisons between intermittent compression treatment regimens, in VLU management. The authors identified only seven randomized controlled trials (including 367 patients in total). Only one trial was at low risk of bias having reported adequate randomization, allocation concealment and blinded outcome assessment. In one trial (80 people) more ulcers healed with intermittent compression than with dressings $(62 \%$ vs. $28 \%$, $\mathrm{P}=0.002$ ). Four trials compared intermittent pneumatic plus compression with compression alone. The first of these trials (45 patients) found increased ulcer healing with intermittent pneumatic plus compression than with compression alone (risk ratio for healing $11.4,95 \%$ confidence interval 1.6 to 82). The remaining three trials (122 patients) found no evidence of a benefit for intermittent pneumatic plus compression compared with compression alone. One small trial (16 patients) found no difference between intermittent compression therapy (without additional compression) and compression bandages alone. One trial compared different ways of delivering intermittent compression and found that rapid pneumatic procedures healed more ulcers than slow procedures ( $86 \%$ vs. $61 \%)$.

In our study we did not provide a professional observation of participant satisfaction, but on the basis of verbal communication of our patients the intermittent pneumatic compression appeared comfortable too. We did not notice any undesirable effects.

Vowden [12] maintains that even with the application of four - layer bandaging the recommended treatment for leg ulcers, patients with reduced mobility have delayed ulcer healing. An extensive review of the literature (in following article) has demonstrated that the use of this treatment on patients with reduced mobility has not been previously studied; yet, analysis of difficult - to - heal ulcer patients would indicate that this method of treatment may be appropriate and requires further study.

In our study stockings (healing rate after two months therapy $56.66 \%$ ) appeared such effective as multi layer bandaging $(58.62 \%)$ and much more efficient than only two - layer compression therapy (16.66\%) and Unna boots (only 20\%). In literature are only a few meta - reports connected with those issues.

O'Meara et al. [20] in their meta - analysis compared effectiveness of two types of compression treatment (four layer bandage and short stretch bandage) in people with venous leg ulceration. Seven eligible trials were identified (887 patients), and patient level data were retrieved for five (797 patients, $90 \%$ of known randomized patients). 
The four layer bandage was associated with significantly shorter time to healing: hazard ratio ( $95 \%$ confidence interval) from multifactorial model based on five trials was 1.31 (1.09 to 1.58), $\mathrm{P}=0.005$. Larger ulcer area at baseline, more chronic ulceration, and previous ulceration were all independent predictors of delayed healing. Data from two trials showed no evidence of a difference in adverse event profiles between the two bandage types. In Cochrane Database from 2012 [23] included forty-eight randomized clinical trials reporting (4321 participants in total). In conclusion authors stated that compression increases ulcer healing rates compared with no compression. Multi-component systems are more effective than single-component systems. Multi-component systems containing an elastic bandage appear to be more effective than those composed mainly of inelastic constituents. Two-component bandage systems appear to perform as well as the multi-layered compression. Patients receiving the multi-layered bandaging heal faster than those allocated the single layered. More patients heal on high-compression stocking systems. Further data are required before the difference between high-compression stockings and the multi-layered bandages can be established.

Cullum et al. [24] searched MEDLINE, CINAHL, EMBASE and the Cochrane Controlled Trials Register (CENTRAL) and stated that multi-layered high compression is more effective than single-layer compression. High-compression hosiery was more effective than moderate compression in preventing ulcer recurrence. The authors concluded that further studies are needed.

In United States and European countries, Unna boots (a noncompliant, plaster-type bandage) are often applied by practitioners in many venous ulcer patients, but unfortunately without randomized controlled clinical trials.

For example, American researchers [25] evaluated the utility of weekly Unna boot therapy in decreasing postoperative edema, inflammation, and morbidity; minimizing postoperative wound care; and improving the rate of wound healing in patients with lower leg surgical defects. In all 10 patients, weekly Unna boot therapy was well tolerated, with high satisfaction levels relating to minimal postoperative wound care, rapid granulation, minimal pain, and excellent esthetic outcome of postoperative wounds. No infections or other complications were noted during the healing process. In weakness of their work authors stated that this was not a randomized well controlled clinical study. In literature there are more controversies $[6,26]$.

\section{Limitations of the study}

To this moment we were unable to present long term results - longer observation than two months (and follow up of recurrence process after 1 and 2 years - to calculate Kaplan - Meier survival analysis with log rank comparisons). Although study outcomes were consistent in each treatment group, the absence of blinding and use of placebo are a limitation of this study that may affect the generalization of the findings. In future we would like to provide quasi compression therapy in control groups and present complete results. We did not use intention-to-treat analysis either.

\section{Conclusion}

The results of our study show that intermittent pneumatic compression systems, stockings and multi layer bandaging are very useful and effective in venous leg ulcer treatment. The two - layer short stretch bandages and Unna boots are not efficient. Future clinical studies and meta-analyses are needed, especially connected with cost of effective therapies and bigger sample size and major omissions according to the CONSORT statement.

\section{Competing Interests}

The authors would like to certify that have no commercial associations with the manufacturers of the equipment described in the manuscript and other conflict of interest.

\section{References}

1. Carpentier $\mathrm{PH}$, Maricq $\mathrm{HR}$, Biro $\mathrm{C}$ et al. Prevalence, risk factors, and clinical patterns of chronic venous disorders of lower limbs: a population based study in France. J Vasc Surg 2004; 40: 650-659

2. Jones RH, Carek PJ. Management of varicose veins. Am Fam Phys 2008; 78(11): 1289-1294

3. Simon DA, Dix FP, McCollum C. Management of venous leg ulcers. BMJ 2004; 328: $1358-1362$

4. van Gent WB, Wilschut ED, Wittens C. Management of venous ulcer disease. BMJ 2010; 34: c6045

5. Collins L, Seraj S. Diagnosis and treatment of venous ulcers. Am Fam Phys 2010; 15: 989-996

6. Kucharzewski M, Kozka M Urbanek T. Topical Treatment of Nonhealing Venous Leg Ulcer with Propolis Ointment. Evid Based Complement Alternat Med 2013;: ID254017

7. Waniczek D, Kozowicz A, Muc - Wierzgon M et al. Adjunct Methods of the Standard Diabetic Foot Ulceration Therapy. Evid Based Complement Alternat Med 2013;: ID243568

8. O'Donnell TF, Balk EF. The need for an Intersociety Consensus Guideline for venous ulcer. J Vasc Surg 2011; 54: 83-90

9. Duby T, Cherry G, Hoffman D et al. A randomized trial in the treatment of venous leg ulcers comparing short stretch bandages, four layer bandage system, and a long stretch - paste bandage system. Wounds 1993; 5: $276-269$

10. Colgan MP, Teevan M, McBride $\mathrm{M}$ et al. Cost comparisons in the management of venous ulceration. $5^{\text {th }}$ European Conference on Advances in Wound Management 1993; : 103

11. Danielsson G, Arfvidsson B, Eklof B, Kistner RL. Reflux from thigh to calf, the major pathology in chronic venous ulcer disease: surgery indicated in the majority of patients. Vasc Endovasc Surg 2004; 38: 209 - 219

12. Vowden K. The use of intermittent pneumatic compression in venous ulceration. Br J Nurs 2001; 10: 491-509

13. Partsch H, Damstra RJ, Tazelaar DJ et al. Multicentre, randomized controlled trial of four - layer bandaging versus short - stretch bandaging in the treatment of venous leg ulcers. VASA 2001; 30: 108 - 113 
14. Meyer FJ, Burnand KG, Lagattola NR, Eastham D. Randomized clinical trial comparing the efficacy of two bandaging regimens in the treatment of venous leg ulcers. Br J Surg 2002; 89: 810

15. O'Brien JF, Grace PA, Perry IJ at al. Randomized clinical trial and economic analysis of four - layer compression bandaging for venous ulcers. Br J Surg 2003; 90: 1307

16. Franks PJ, Moody M, Moffat CJ at al. Randomized trial of cohesive short stretch versus four - layer bandaging in the management of venous ulceration. Wound Rep Regen 2004; 12: 157 - 160

17. Junger M, Wollina U, Kohnen R, Rabe E. Efficacy and tolability of an ulcer compression stocking for therapy of chronic venous ulcer compared with a beelow - knee compression bandage: results from a prospective, randomized, multicentre trial. Curr Med Res Opin 2004; 20: 1613 - 1623

18. Vanscheidt W, Kohnen R, Achhammer I. Tubulcus - Kompressionstherapie des venosen ulcus cruris. Phlebologie 2004; 33: 12 - 16

19. Brizzio EO, Blatter W, Rossi G. et al. Healing venous ulcers with different modalities of leg compression: unexpected findings of a pilot study, Phlebologie 2006; 35: 349-355

20. O'Meara S, Tierney J, Cullum N et al. Four layer bandage compared with short stretch bandage for venous leg ulcers: review and meta-analysis of randomized controlled trials with data from individual patients. BMJ 2009; 338: 1344-1353

21. Gilman TH. Parameter for measurement of wound closure. Wounds 1990; 3: 95-101

22. Nelson EA, Mani R, Thomas $\mathrm{K}$ et al. Intermittent pneumatic compression for treating venous leg ulcers. Cochrane Database Syst Rev 2011; 16: CD001899

23. O'Meara S, Cullum N, Nelson EA, Dumville JC. Compression for venous leg ulcers. Cochrane Database Syst Rev 2012; 14: CD000265

24. Cullum N, Nelson EA, Flemming K, Sheldon T. Systematic reviews of wound care management: beds; compression; laser therapy, therapeutic ultrasound, electrotherapy and electromagnetic therapy. Health Technol Assess 2001; 5: $1-221$

25. Stebbins WG, Hanke CW, Petersen J. Enhanced healing of surgical wounds of the lowerleg using weekly zinc oxide compression dressings. J Dermatol Surg 2011; 37: 158-165

26. Schaum KD. Unna boots versus multilayered, sustained, graduated high compression bandage systems. Ostomy Wound Manage 2005; 51: 30 